\title{
UK scientists celebrate budget reprieve
}

\section{Core science funding has escaped cuts, but capital budgets will feel the squeeze.}

\section{BY GEOFF BRUMFIEL}

A $\mathrm{n}$ unexpected bouquet of white lilies and roses greeted David Willetts, Britain's minister for science, when he arrived at a press conference on 20 October to announce the government's plans for research spending over the next four years.

In better times, he might have been met with a barrage of rotten fruit. The research base will continue to be funded at its current level, $£ 4.6$ billion (US $\$ 7.2$ billion), for the four-year review period - which amounts to an effective cut of $10 \%$ if inflation projections are factored in. In addition, an essential funding stream for large projects will probably be substantially cut, along with research in many government departments.

But these are not better times. Faced with a record deficit of $£ 109$ billion, the British government is slashing expenditure by an average of $19 \%$ across its departments. In the face of such austerity, Willetts called the science budget a "fantastic deal", and many agreed. "I'm genuinely relieved," says William Cullerne Bown, founder of the science-policy newsletter Research Fortnight, who presented Willetts with the flowers. John Beddington, the government's chief scientific adviser, says that officials such as George Osborne, the Chancellor of the Exchequer, were won over by arguments from high-profile scientists and industrialists that cuts could hinder long-term growth of the British economy.

The $£ 4$.6-billion sum includes funding for the nation's research councils, which dole out grants to scientists, and money for 'quality related' research funds, which universities can prioritize as they choose. Money for health research - channelled through the Department of Health, and the Medical Research Council (MRC) - will remain flat in real terms (once inflation is factored in), amounting to a modest increase in cash terms. Other research councils will have to bear a greater burden of cuts to compensate for the MRC's good fortune. All funding has been assured for the four-year period, according to Willetts.

The budget also provides $£ 220$ million for the research councils' highest future priority - a medical research centre to be located in the heart of London. Documents obtained by Nature under freedom of information legislation show that the councils deemed the UK Centre for Medical Research \& Innovation such a high priority that they declined to even rank it against other projects when submitting budget documents earlier this year. An upgrade to the Diamond synchrotron in Oxfordshire is also assured. "The outcome is better than most of us had hoped for," says Martin Rees, president of the Royal Society, Britain's national science academy.

But money for infrastructure and subscriptions to large international projects is not "The outcome protected, according to The outcome Willetts. The Departis better than ment for Business, Innomost of us had vation and Skills, which hopedfor." funds the councils, will see its overall 'capital' budget fall by $44 \%$ to $£ 1$ billion in $2014-15$ (see 'Capital crash').

That money pays for everything from radio telescopes to Antarctic research stations. In particular, the cuts will hit the Science \& Technology Facilities Council (STFC), which funds particle physics and astronomy. The council, which has struggled financially for years, has been told to prepare for its capital funding to fall by a third, according to documents seen by Nature. That could jeopardize Britain's participation in organizations such as the European Southern Observatory.

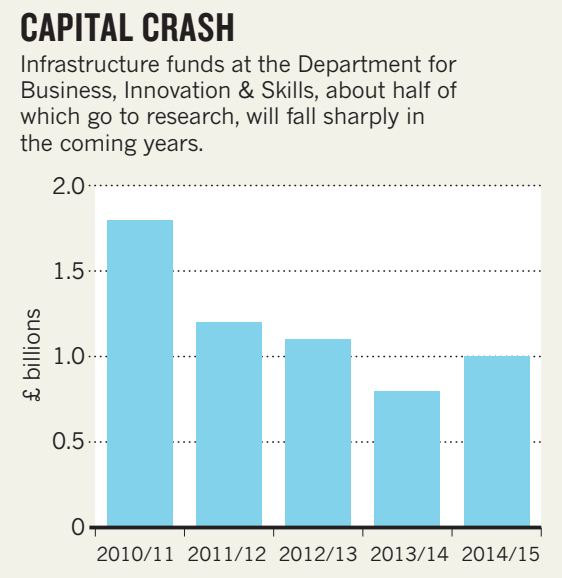

Research funding in government departments will also be under pressure. The annual $£ 650$-million basic-research budget of the Ministry of Defence will probably face a "modest" cut, says Willets. The Department for Environment, Food and Rural Affairs, which conducts animal health and environmental research, will face "substantial but manageable" cuts to its £95-million annual core research budget, according to Chris Gaskell, who heads the department's independent scientific advisory council. Beddington says that he will be consulted before any departmental cuts are made final. "It doesn't mean I can veto them, but it does mean that it will be discussed," he says.

The final details of what is cut, and how, will emerge in the weeks and months to come (see Nature 467, 894; 2010), but for now, the mood is buoyant. After handing his flowers to an aide, Willetts turned to the assembled reporters and policy-makers with a broad smile. "We'll have the hugs and kisses later on," he joked. SEE WORLD VIEW P.1007

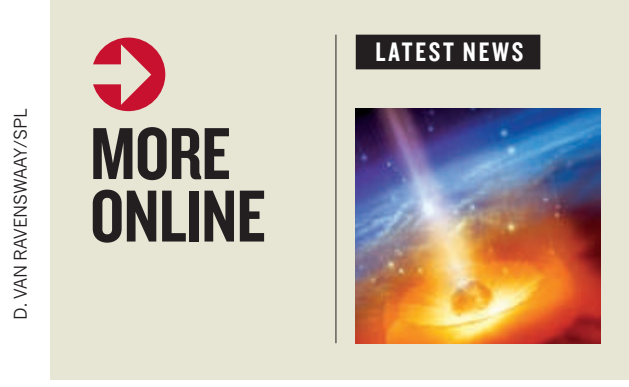

\begin{tabular}{l|l} 
- NASA & - Rise in space tourism could \\
charged & accelerate climate change \\
with leading & go.nature.com/lfigec \\
asteroid & Alternative yardstick to measure the \\
response & Universe go.nature.com/fmxrog \\
go.nature.com/ & - Ancient chimp virus brought 'back \\
hedzcu & to life' go.nature.com/qhbqOK
\end{tabular}

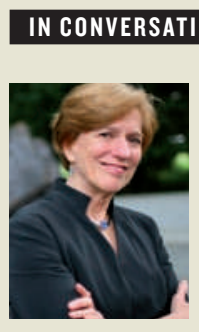

Former US science adviser Nina Fedoroff explains why people can achieve more than governments. go.nature.com/rxxhdr 